\title{
Cyclic 3',5'-GMP Independent Protein Kinase at the Outer Surface of Intact Ehrlich Cells
}

\author{
GUNNAR RONQUIST, GUNNAR AGREN, STEN EKLUND and \\ CHRISTER WERNSTEDT
}

From the Institute of Medical and Physiolngical Chemistry, Uppsala, Sweden

\begin{abstract}
The phosphoryl group transfer from $\left(\gamma^{32}\right.$ P)ATP into acceptor proteins by an endogenous protein kinase at the surface of Ehrlich cells has been further studied as regards possible stimulation by different concentrations of dibuturyl cyclic guanosine monophosphate $\left(3^{\prime}, 5^{\prime}\right.$-GMP). Using the endogenous acceptor protein of the surface of Ehrlich cells the cyclic nucleotide had no stimulatory effect on the protein kinase of the plasma membrane. The lack of stimulatory action of the cyclic nucleotide was also observed when an exogenous acceptor protein was present. Instead, a slight inhibitory effect was usually seen in both types of experiments. Labeled phosphorylserine was always in excess of labeled phosphoryl threonine. Both were isolated from hydrolyzed acceptor proteins. The lack of stimulation by a cyclic nucleotide on the phosphorylation of acceptor protein(s) on the cell surface does not rule out a regulatory function by the protein kinase of the plasma membrane. Instead, we propose an autoregulatory mechanism for the phosphorylation at the cell surface. This mechanism is based upon the high sensitivity of the enzyme to Ca-ions.
\end{abstract}

\section{INTRODUCTION}

The presence of endogenous protein kinase at the surface of Ehrlich cells catalyzing the phosphorylation of endogenous membrane protein(s) was first described $1970(1,22)$ and in some following reports $(2,4,23,24)$. Schlatz \& Marinetti described in 1971 the cyclic AMP-dependent phosphorylation of isolated rat liver plasma membrane by a partially purified protein kinase from rat liver (28). In a similar experiment Kinzel \& Mueller (13) were able to demonstrate the phosphorylation of endogenous acceptor proteins at the surface of intact HeLa cells in the presence of a protein kinase isolated from rat skeletal muscle and $\left(\gamma^{32} \mathrm{P}\right)$ ATP in the external medium. This reacting was also stimulated to a limited degree by cyclic AMP. Protein kinasecatalyzed membrane phosphorylations, either involving the endogenous protein kinase and an ex- trinsic acceptor protein or an extrinsic enzyme and the endogenous acceptor or where both enzyme and acceptor are endogenous, have subsequently been published for many membrane systems (for references, see ref. 4). Few of these protein kinasemediated reactions have been cyclic AMPindependent $(5,6,10,21,31,34)$ including the plasma membrane phosphorylation system for the Ehrlich cell (4, 23, 24).

Many cyclic AMP-dependent protein kinases are, however, known to be activated by more than one $3^{\prime}, 5^{\prime}$-cyclic nucleotide. Hence, cyclic GMP-specific kinases have in recent years been found in pig lung (16), guinea pig fetal lung (19), bovine adrenal glands (30), rat pancreas (33) and cerebellum (11), mammalian smooth muscle (7) and heart tissue (15, 17).

Furthermore, it has been claimed that membrane-associated, cyclic GMP-dependent protein kinases might mediate the effects of cholinergic agents in a manner quite analogous to the actions of particulate and soluble cyclic AMP-dependent protein kinases in mediating cellular responses to polypeptide hormones, adrenergic agents and neurotransmitters (26).

Cyclic GMP-stimulated protein kinase differs from that stimulated by cyclic AMP as regards some physicochemical properties $(19,20,32)$. Nevertheless, enzymatic properties for both types of protein kinases are the same as regards the requirements of binding steps at 3 different sites in the molecule, namely the binding of cyclic nucleotide for activation, the binding of ATP and $\mathrm{Mg}^{2+}$ and the binding of protein substrate for the reaction (14).

Smooth muscle is the only tissue in which any endogenous substrate proteins for the cyclic GMPdependent protein kinases have so far been found (9), and it was of interest to extend the work on the 
Table I. Effect of dibuturylcyclic GMP on the endogenous phosphorylation of the surface membrane of Ehrlich cells

The figures denote the phosphoryl group transfer in $\mathrm{nmol} / 1 \times 10^{8}$ cells per min at $37^{\circ} \mathrm{C}$ into endogenous acceptor protein

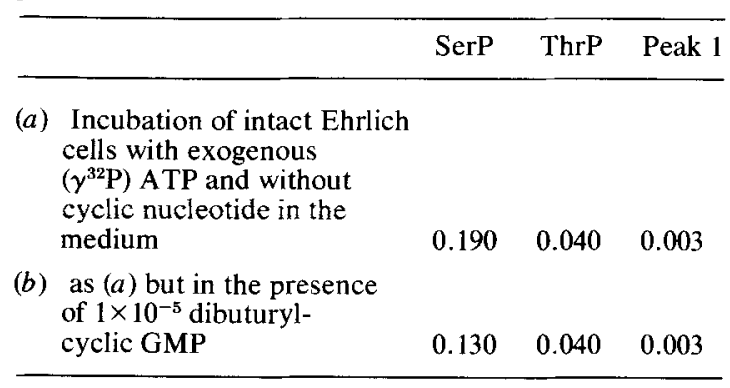

endogenous protein kinase(s) as well as the endogenous acceptor proteins at the surface of Ehrlich cells so as to encompass even a study of the possible cyclic GMP dependency. The present results demonstrate the lack of influence of cyclic GMP in the concentration range $1 \times 10^{-4} \mathrm{M}-1 \times 10^{-7}$ $M$ on the protein kinase system at the outer surface of Ehrlich cells. The steric dispositions of the regulator to the catalytic subunit have been investigated by means of dibuturyl cyclic GMP. The reaction was also studied with an exogenous phosphoryl group acceptor protein as well as with a purified membrane fraction.

\section{MATERIAL AND METHODS}

Materials. All chemicals were of analytical grade, $\left(\gamma^{32} \mathrm{P}\right)$ ATP was purchased from NEN chemicals, $\mathrm{GmbH}$, Frankfurt am Main, Germany. Unlabeled ATP (sodium form), cyclic and dibuturyl cyclic GMP as well as phosvitin were all obtained from Sigma Chemical Company, St. Louis, Mo., USA.

Preparation of tumor cells. The Ehrlich ascites tumour cells were grown for 8-10 days in 5-week-old male Swiss albino mice obtained from the Anticimex Breeding Farm, Norrviken, Stockholm. The tumour cells were separated by centrifugation of the ascitic fluid, which had been diluted without delay 10-fold with ice-cold Krebs-Ringer bicarbonate medium, in order to diminish the tendency of cell agglutination. The cells were then washed twice in the Krebs-Ringer bicarbonate medium. Final washing was performed with a medium of $130 \mathrm{mM}$ $\mathrm{NaCl}$ and $25 \mathrm{mM} \mathrm{KCl}$ for experiments with intact cells. For the preparation of a membrane fraction the cells were finally washed in a sucrose-(0.250 M)-tris-glycylglycine $(0.016 \mathrm{M})$ buffer, $\mathrm{pH} 8.0$, also containing $2 \mathrm{mM} \mathrm{CaCl}_{2}$, followed by centrifugation (25). The washings of intact cells were carried out in the International Refrigerated Centrifuge by acceleration for $10-15 \mathrm{sec}$ up to at most
$5700 \mathrm{rpm}$ followed by retardation for about $2 \mathrm{~min}$. All preparatory steps were carried out at $4^{\circ} \mathrm{C}$.

Preparation of plasma membrane fraction. The procedure described by Ronquist \& Christensen (25) was followed exactly. The final membrane fraction was suspended in $130 \mathrm{mM} \mathrm{NaCl}$ and $25 \mathrm{mM} \mathrm{KCl}$ in a concentration corresponding to about $20 \mathrm{mg}$ membrane protein per $\mathrm{ml}$.

Incubation procedure. Incubations were performed directly after the preparation of the cells and the membrane fraction. About $1 \times 10^{8}$ cells or a membrane fraction corresponding to $20 \mathrm{mg}$ membrane protein were suspended in an incubation volume of $9.5 \mathrm{ml}$ consisting of $130 \mathrm{mM} \mathrm{NaCl}$ and $25 \mathrm{mM} \mathrm{KCl}$. It contained in addition $350 \mu$ moles of Tris-acetic acid buffer, $\mathrm{pH} 7.5,20 \mu$ moles of $\mathrm{MgCl}_{2}, 10$ $\mu$ moles of $\mathrm{Na}_{2} \mathrm{HPO}_{4}$ (unlabeled), $5 \mu$ moles of glutathione (reduced form) and $0.5 \mu$ moles of $\left(\gamma^{32} \mathrm{P}\right) \mathrm{ATP}$. In some experiments, $2.5 \mu$ moles of phosvitin were also included. Dibuturylcyclic GMP, when present, was used in final concentrations of $1 \times 10^{-4} \mathrm{M}-1 \times 10^{-7} \mathrm{M}$. The commercial phosvitin preparation was free from protein kinase activity. Incubation was performed at $37^{\circ} \mathrm{C}$ and teminated after $1 \mathrm{~min}$ by rapid centrifugation. The entire centrifugation procedure did not exceed $30 \mathrm{sec}$. The supernatant representing the external medium including the acceptor protein in most experiments was immediately precipitated with trichloroacetic acid (10\% final concentration). In order to completely precipitate the low molecular weight acceptor protein, $50 \mathrm{mg}$ of bovine albumin were added to the precipitating agent and the cell pellets were precipitated with trichloroacetic acid. The precipitation was allowed to proceed for at least $24 \mathrm{~h}$ at $4^{\circ} \mathrm{C}$. The precipitates were washed once with $10 \%$ trichloroacetic acid containing $5 \mathrm{mM}$ of unlabeled orthophosphate and $1 \mathrm{mM}$ of ATP.

In order to remove nucleic acid and phospholipids, the precipitate was treated according to Schneider (29). Partial hydrolysis of the Schneider protein was performed using the method of Lipmann (18). Labeled phosphorylserine and phosphorylthreonine and phosphopeptides were isolated by ion exchange chromatography, as described previously (23). A radiometric determination of the different fractions from column chromatography was carried out in a Nuclear Chicago Scintillation Counter by measuring the Cerenkov radiation.

\section{RESULTS}

During the separation process two other $\left({ }^{32} \mathrm{P}\right)$ labelled phosphopeptides are recovered in addition to the $\left({ }^{32} \mathrm{P}\right)$-labelled phosphorylserine and phosphorylthreonine. Those peptides have been called peak 1 and 2, respectively (23). Table I illustrates the lack of stimulation by $1 \times 10^{-5} \mathrm{M}$ dibuturylcyclic GMP upon the endogenous membrane-associated protein kinase on phosphorylation of the endogenous phosphoryl group acceptor in the surface membrane of intact Ehrlich cells. Instead a slight decrease of the degree of 
Table II. Effect of various concentrations of dibuturylcyclic GMP on the phosphorylation of an exogenous acceptor protein by a protein kinase associated with the surface membrane of Ehrlich cells

The figures denote the phosphoryl group transfer in $\mathrm{nmol} / \mathrm{l} \times 10^{8}$ cells per min at $37^{\circ} \mathrm{C}$ into acceptor protein

\section{SerP ThrP Peak 1}

(a) Phosvitin as exogenous phosphoryl group acceptor together with intact Ehrlich cells

$\begin{array}{lll}0.580 & 0.225 & 0.103\end{array}$

(b) as (a) plus $1 \times 10^{-7} \mathrm{M}$ dibuturylcyclic GMP

$\begin{array}{lll}0.540 & 0.231 & 0.098\end{array}$

(c) as (a) plus $1 \times 10^{-6} \mathrm{M}$ dibuturylcyclic GMP

0.473

0.197

0.076

(d) as (a) plus $1 \times 10^{-4} \mathrm{M}$ dibuturylcyclic GMP

$0.482 \quad 0.173$

0.081

phosphorylation is seen in the presence of the cyclic nucleotide. This observation is in agreement with earlier findings with cyclic AMP $(4,23)$. The aliphatic cyclic nucleotide is assumed to penetrate the plasma membrane. Thus, providing the cyclic GMP-binding subunit is in trans-position to the catalytic subunit, it would nevertheless be possible for the added cyclic nucleotide to react. However, in experiments with intact cells the possibility of binding to the receptor site by endogenous cyclic nucleotide(s) cannot be ruled out.

The lack of stimulation by different concentrations of dibuturyl cyclic GMP on the phosphorylation of phosvitin as exogenous phosphoryl group acceptor in the presence of intact Ehrlich cells is shown in Table II. Instead, a slight inhibitory action is again seen, especially at the two higher concentrations. The incorporation ratio between phosphorylserine and phosphorylthreonine remained constant and about 2.5 , regardless of the absince or presence of different concentrations of dibuturylcyclic GMP in the incubation media.

As mentioned before, the possibility of a reaction between cellular cyclic GMP and the receptor site of the regulatory subunit on the inner surface of the intact membrane could not be ruled out. In such a case additional cyclic GMP would have no or very little effect. Therefore, experiments were also performed on a purified membrane preparation mainly consisting of vesicles (25). It is evident from Table III that no stimulatory effect is exerted by $1 \times 10^{-6} \mathrm{M}$ dibuturylcyclic GMP in the medium also containing phosvitin and the membrane vesicles from Ehrlich cells. Instead, a small inhibitory effect is seen, consistent with the findings for the intact cells. The incorporation ratio between phosphorylserine and phosphorylthreonine was increased about 3 times compared with that for intact cells.

\section{DISCUSSION}

We propose that the protein kinase of the plasma membrane of Ehrlich cells is not dependent on either cyclic GMP in accordance with the present work or cyclic AMP $(4,23)$. Furthermore, at least some of this protein kinase is associated with the outer surface of the Ehrlich cell membrane.

An external protein kinase activity in rat $C-6$ glioma cells was claimed in a recent report to be cyclic AMP-dependent (27). In the experimental system used, histone was the external phosphoryl group acceptor. No data were presented concerning any phosphorylation of a possible endogenous acceptor protein of the rat glioma cells, nor was any other acceptor protein used (27). We have also studied the protein kinase at the outer surface of human glioma cells (3), as well as of Ehrlich cells (24). In both types of cells we found a stimulation by cyclic AMP but only when histone was the exogenous phosphoryl group acceptor. Furthermore, in the case of Ehrlich cells the maximal phosphorylation with histone as the exogenous acceptor was 8 times lower than with phosvitin as the exogenous

Table III. Effect of dibuturylcyclic GMP on the phosphorylation of an exogenous acceptor protein by a protein kinase associated with a plasma membrane preparation from Ehrlich cells

The figures denote the phosphoryl group transfer in $\mathrm{nmol} / \mathrm{mg}$ Schneider protein of membrane vesicles per min at $37^{\circ} \mathrm{C}$ into acceptor protein. For comparison with Tables 1 and $2,1 \times 10^{8}$ Ehrlich cells correspond to about $15 \mathrm{mg}$ Schneider protein from membrane vesicles prepared from Ehrlich cells

\section{SerP ThrP Peak 1 Peak 2}

(a) Phosvitin as exogenous phosphoryl group acceptor together with membrane vesicles from Ehrlich cells

$\begin{array}{llll}0.451 & 0.069 & 0.022 & 0.004\end{array}$

(b) as (a) plus $1 \times 10^{-6} \mathrm{M}$ dibuturylcyclic GMP $\begin{array}{lllll}\text { in incubation medium } & 0.440 & 0.046 & 0.022 & 0.004\end{array}$ 
acceptor under otherwise same experimental conditions (24). Also, the amount of phosphorylation of histone as the exogenous acceptor did not exceed that of the endogenous acceptor of the Ehrlich cells (24). The endogenous phosphorylation of Ehrlich cell membranes is not stimulated by cyclic AMP (23). We have therefore interpreted the effect of cyclic AMP with histone as the exogenous acceptor protein as secondary, e.g. interfering with the basic histone-protein interaction with the netto-negative charges of the intact cells (24). However, the existence of at least two or more protein kinases at the Ehrlich cell surface with different properties $v i s-\grave{a}-$ vis cyclic nucleotides cannot be excluded.

The experiments with different concentrations of cyclic GMP in the medium (Table II) showed a very constant phosphorylserine to phosphorylthreonine ratio throughout the experiments, thus favouring the view of homogeneity as regards protein kinase activity in the surface membrane of Ehrlich cells. The labelled phosphorylserine is always in excess of labelled phosphorylthreonine $(2,4,23$, 24). This observation has been confirmed to be valid also for HeLa cells and SV3T3-ts cells in a recent work (12).

A phosphorylation and dephosphorylation cycle of membrane proteins have been suggested to occur, thereby changing their charge and conformation (8). Furthermore, such changes might affect the interaction of the membrane proteins with the neighbouring lipids or lipoprotein complexes resulting in the aggregation of intramembrane particles and relative increase in the exposed free lipid bilayer phase of the membrane (8).

A cyclic nucleotide dependency of the protein kinase in the surface membrane does not appear to be obligatory. Instead we propose an autoregulatory mechanism based upon the actual $\mathrm{Ca}^{2+}$ concentration in the microenvironment of the surface membrane. We found a strong inhibitory effect by $\mathrm{Ca}^{2+}$ on the endogenous protein kinase at the membrane surface of Ehrlich cells (23). Maximal activity was obtained with $\mathrm{Mg}^{2+}, \mathrm{Na}^{+}$and $\mathrm{K}^{+}$ with no $\mathrm{Ca}^{2+}$ in the system. When half the amount of $\mathrm{Mg}^{2+}$ was stoichiometrically exchanged for $\mathrm{Ca}^{2+}$ the protein kinase activity decreased by about $50 \%$ and when all $\mathrm{Mg}^{2+}$ was replaced by $\mathrm{Ca}^{2+}$, more than $80 \%$ of the activity was lost. Therefore, in a maximally dephosphorylated state of the surface membrane of the cell, the $\mathrm{Ca}^{2+}$ content of the microenvironment of the cell surface might be low and the protein kinase activity high, while in a maximally phosphorylated state $\mathrm{Ca}^{2+}$ ions are electrostatically attracted and therefore the protein kinase activity is lower.

\section{ACKNOWLEDGEMENTS}

This investigation was supported by a grant from the Swedish Medical Research Council (Project No B76-13X00228-12A).

\section{REFERENCES}

1. Agren, G. \& Ronquist, G.: Isolation of ${ }^{32} \mathrm{P}$-labelled phosphorylserine from Ehrlich mouse-ascites tumour cells suspended in an isotonic medium containing ${ }^{32} \mathrm{P}$ labelled adenosine triphosphate. Acta Physiol Scand 79: $125-128,1970$.

2. - Isolation of ${ }^{32} \mathrm{P}$-labelled phosphorylserine and phosphorylthreonine from Ehrlich mouse-ascites tumour cells, suspended in an isotonic medium containing ${ }^{32} \mathrm{P}$-labelled nucleoside triphosphates or inorganic pyrophosphates. Acta Chem Scand 25: 2931-2934, 1971.

3. - $\left.{ }^{32} \mathrm{P}\right)$ Phosphoryl transfer by endogenous protein kinase at the glia and glioma cell surface in culture into extrinsic acceptor proteins. Acta Physiol Scand 92: 430-432, 1974.

4. - Phosphorylation of endogenous membrane proteins by endogenous protein kinase at the outer surface of Ehrlich cells. Upsala J Med Sci $81: 129$ 134, 1976.

5. Andrew, C., Roses, A. D., Almon, R. R. \& Appel, S. H.: Phosphorylation of membranes: Identification of a membrane-bound protein kinase. Science 182 : 927-929, 1973.

6. Bacalao, J. \& Rieber, M.: On the properties of membrane-associated protein kinase from chinese hamster ovary cells. FEBS Lett 37:37-41, 1973.

7. Casnellie, J. E. \& Greengard, P.: Guanosine 3',5' monophosphate-dependent phosphorylation of endogenous substrate proteins in membranes of mammalian smooth muscle. Proc Natl Acad Sci USA 7I: 1891-1895, 1974.

8. Gazitt, Y., Ohad, I. \& Loyter, A.: Phosphorylation and dephosphorylation of membrane proteins as a possible mechanism for structural rearrangement of membrane components. Biochim Biophys Acta 436:1-14, 1976.

9. Greengard, P.: Possible role for cyclic nucleotides and phosphorylated membrane proteins in postsynaptic actions of neurotransmitters. Nature 260:101-108, 1976.

10. Ho, R., Russell, T., Asakarva, T. \& Snyder, R. P.: Influence on adipocyte plasma membrane bound protein kinase by feedback regulator. J Cyc Nucleo Res 1:349-358, 1975.

11. Hofman, F. \& Sold, G.: A protein kinase activity from rat cerebellum stimulated by guanosine-3' $5^{\prime}$-monophosphate. Biochem Biophys Res Commun 49: $1100-1107,1972$. 
12. Kinzel, V., Kübler, D., Mastro, A. M. \& Rosengurt, E.: Phosphoproteins of the cell surface as generated by endogenous or exogenous protein kinase: stability of the ${ }^{32}$ P-labelled product. Biochim Biophys Acta 434: 281-285, 1976.

13. Kinzel, V. \& Mueller, G.: Phosphorylation of surface proteins of HeLa cells using an exogenous protein kinase and ( $\gamma^{32}$ P) ATP. Biochim Biophys Acta 322: 337-351, 1973.

14. Kobayashi, R. \& Fang, V.: Studies on cyclic GMPdependent protein kinase properties by blue dextransepharose chromatography. Biochem Biophys Res Commun 69: 1080-1087, 1976.

15. Kuo, J. F., Davis, C. W. \& Tse, J.: Depressed cardiac cyclic GMP-dependent protein kinase in spontaneously hypertensive rats and its further depression by guanethidine. Nature $261: 335-336,1976$.

16. Kuo, J. F., Kuo, W-N., Shoji, M., Davis, C. W., Seery, V. L. \& Donelly, T. E.: Purification and general properties of guanosine $3^{\prime}, 5^{\prime}$-monophosphatedependent protein kinase from guinea pig fetal lung. J Biol Chem 251: 1759-1766, 1976.

17. Kuo, J-F., Lee, T-P., Reyes, P. L., Walton, K. G., Donnelly, T. E. \& Greengard, P.: Cyclic nucleotide-dependent protein kinases $X$. An assay method for the measurement of guanosine 3',5'-monophosphate in various biological materials and a study of agents regulating its levels in heart and brain. $J$ Biol Chem 247: 16-22, 1972.

18. Lipmann, F.: Über die Bindung der Phosphosäure in Phosphoproteinen. I. Mitteilung: Isolierung einer phosphorhaltigen Aminosäure (Serinphosphosäure) aus Casein. Biochem Z 262:3, 1933.

19. Nakazava, K. \& Sano, M.: Partial purification and properties of guanosine 3',5'-monophosphate-dependent protein kinase from pig lung. $J$ Biol Chem 250: 7415-7419, 1975.

20. Nishiyama, K., Katakami, H., Yamamura, H., Takar, Y., Shimomura, R. \& Nishizuka, Y.: Functional specificity of guanosine $3^{\prime}, 5^{\prime}$-monophosphate-dependent and adenosine $3^{\prime}, 5^{\prime}$-monophosphate-dependent protein kinases from silkworm. J Biol Chem 250: 1297-1300, 1975.

21. Prasad, K. N., Fogleman, M., Gaschler, M., Sinha, P. K. \& Brown, L.: Cyclic nucleotide-dependent protein kinase activity in malignant and cyclic AMP-induced "differentiated" neuroblastoma cells in culture. Biochem Biophys Res Commun 68: 1248-1254, 1976.

22. Ronquist, G. \& Agren, G.: Isolation of ${ }^{32} \mathrm{P}$-labelled phosphorylthreonine from Ehrlich mouse-ascites tumour cells suspended in an isotonic medium containing ${ }^{32}$ P-labelled adenosine triphosphate. Acta Chem Scand 24: 728-729, 1970.

23. - Isolation of ${ }^{32} \mathrm{P}$-labelled phosphorylserine and phosphorylthreonine from Ehrlich mouse-ascites tumour cells suspended in different isotonic media containing ${ }^{32} \mathrm{P}$-labelled adenosine triphosphate. Acta Chem Scand 28: 1169-1174, 1974.

24. - $\left({ }^{32} \mathrm{P}\right)$ phosphoryl transfer by endogenous protein kinase at the Ehrlich cell surface into extrinsic acceptor proteins. Upsala J Med Sci 79: 138-142, 1974.

25. Ronquist, G. \& Christensen, H.: Amino acid stimula- tion of alkali-metal-independent ATP cleavage by an Ehrlich cell membrane preparation. Biochim Biophys Acta 323: 337-341, 1973.

26. Rubin, C. S. \& Rosen, O. M.: Protein phosphorylation. Annu Rev Biochem 44: 831-877, 1975.

27. Schluger, E-J. \& Köhler, G.: External cyclic AMPdependent protein kinase activity in rat C-6 glioma cells. Nature 260: 705-707, 1976.

28. Schlatz, L. \& Marinetti, G. V.: Protein kinase mediated phosphorylation of the rat liver plasma membrane. Biochem Biophys Res Commun 45: 51-56, 1971.

29. Schneider, W. C.: Phosphorous compounds in animal tissues. 1. Extraction and estimation of desoxypentose nucleic acid. J Biol Chem 151:293-303, 1945.

30. Shima, S., Mitsunaga, M., Kawashima, Y., Taguchi, S. \& Nakao, T.: Studies on cyclic nucleotides in the adrenal gland. III. Properties of cyclic AMP- and GMP-dependent protein kinases in the adrenal gland. Biochim Biophys Acta 341: 56-64, 1974.

31. Steiner, M.: Endogenous phosphorylation of platelet membrane proteins. Arch Biochem Biophys 171: 245-254, 1975.

32. Takai, Y., Nishiyama, K., Yamamura, H. \& Nishizuka, Y.: Guanosine 3',5'-monophosphatedependent protein kinase from bovine cerebellum. Purification and characterization. J Biol Chem 250: $4690-4695,1975$.

33. van Leemput, M., Camus, J. \& Christophe, J.: Cyclic nucleotide-dependent protein kinases of the rat pancreas. Biochem Biophys Res Commun 54: 182$190,1973$.

34. Weller, M., Virmaux, N. \& Mandel, P.: Lightstimulated phosphorylation of rhodopsin in the retina: The presence of a protein kinase that is specific for photobleached rhodopsin. Proc Natl Acad Sci USA $72: 381-385,1975$.

Received August 28, 1976

Address for reprints:

Gunnar Ågren, M.D.

Institute of Physiological and Medical Chemistry

Box 575

S-751 23 Uppsala

Sweden 